\title{
Comparison Between USGS PSHA Modification and Openquake in Determining Bedrock Acceleration With Probability of Exceedance $2 \% 50$ Years, Case Study: Central Sulawesi, Indonesia
}

Arifan Jaya Syahbana ( $\nabla$ arifanjaya84@gmail.com )

Institut Teknologi Bandung https://orcid.org/0000-0003-2204-7355

Anggun Mayang Sari

Institute of Neurological Sciences Research Center for Geotechnology

Okta Fajar Saputra

Indonesian Institute of Sciences Research Center for Geotechnology

Dega Damara Aditramulyadi

Bandung Institute of Technology: Institut Teknologi Bandung

Masyhur Irsyam

Bandung Institute of Technology

Hendriyawan Hendriyawan

Bandung Institute of Technology: Institut Teknologi Bandung

M Asrurifak

National Institute of Science and Technology

Research

Keywords: Bedrock Acceleration, Probability of Exceedance 2\% 50 Years period, Central Sulawesi

Posted Date: November 23rd, 2020

DOI: https://doi.org/10.21203/rs.3.rs-106890/v1

License: (c) (i) This work is licensed under a Creative Commons Attribution 4.0 International License.

Read Full License 


\section{Abstract}

Several destructive earthquake events with large magnitude struck Central Sulawesi, Indonesia include on August 23, 1982 (5.4 Mw), October 25, 1983 (5.8 Mw), October 31, 1983 (6.0 Mw), July 221996 (7.0 Mw), September 28, 1997 (5.9 Mw), October 10, 1998 (6.1 Mw), May 4, 2000 (6.5 Mw), May 8, 2010 (5.8 Mw), February 15, 2011 (6.1 Mw), May 29, 2017 (6.6Mw) and September 28, 2018 (5.9Mw; 7.4Mw). Especially in the last incident, there was an interesting phenomenon, the occurrence of tsunamis with the cause of the mechanism of strike-slip and liquefaction with a deformation reaching several hundred meters. With the effects of the earthquake, this paper aims to review the earthquake side, especially the acceleration study in bedrock using the modified USGS PSHA software in attenuation (GMPE) and OpenQuake for 2475 years return period ( $2 \%$ probability exceeded in 50 years). The earthquake data used was the 19002016 earthquake catalog adopted by the Indonesian National Earthquake Study Center. The results obtained are earthquake acceleration using modified USGS PSHA generate greater value mainly in areas close to Batui Fault. In the combination analysis conducted at the end of this study, the acceleration range values are the same as the 2017 Indonesia Earthquake Map. Still, they have different zonation patterns in the central part of Central Sulawesi Province, where there is an enlarged zone of $0.6-0.7 \mathrm{~g}$.

\section{Introduction}

Indonesia's location, a meeting between the Australian plate, the Philippines, and Europe, makes this area vulnerable to earthquake hazards (McCaffrey 2009; Faris and Fawu 2014; Natawidjaja et al. 2017). In quantifying earthquake hazards, worldwide researchers use both free or paid software to analyze them (Kara and Durukan 2017; Syahbana et al. 2020). In the process, the comparison between software is often done by researchers in testing its reliability. This manuscript will deliver comparison software include USGS PSHA modification and OpenQuake, which are both freely available types. The denotation of improvement here is USGS software (Petersen et al. 2008), which has been done by adding attenuation or Ground Motion Prediction Equation (GMPE) as used national team of Indonesia when made the 2017 Indonesian Earthquake National Map (PusGen 2017; Irsyam et al. 2020). In its history, the USGS PSHA software is stopped in development since 2014; thus, GMPE existing database ends with the year. This software consists of three modules distinguished based on earthquake sources' mechanism to be analyzed: shallow and deep background sources, fault sources, and megathrust subduction sources. For more details, it will be explained in the next chapter.

On the other hand, OpenQuake is a software developed in several countries in analyzing seismicity in their respective regions, including in Indonesia (Field et al. 2003; Pagani et al. 2014; Silva et al. 2014; GEM 2016). This program also requires us to compile a logic tree (both magnitudes, GMPE, or other parameters), provide earthquake sources and other inputs.

The study area chosen in this paper is Central Sulawesi Province, Indonesia. This location is one of the provinces located in the country of Indonesia, Southeast Asia. Based on a seismotectonic point of view, this area is close to the megathrust of North Sulawesi, the Philippines, and 50 faults/segment faults at 
shallow depths that are less than $20 \mathrm{~km}$ (Figure 1). With these conditions, the province was hit by several earthquake events. Some of the events that struck with great magnitude (Setiyono et al. 2019) were on August 23, 1982 (5.4 Mw), October 25, 1983 (5.8 Mw), October 31, 1983 (6.0 Mw), July 22, 1996 (7.0 Mw), September 28, 1997 (5.9 Mw), October 10, 1998 (6.1 Mw), May 4, 2000 (6.5 Mw), May 8, 2010 (5.8 Mw), February 15, 2011 (6.1 Mw), May 29, 2017 (6.6Mw) and September 28, 2018 (5.9Mw; 7.4Mw).

Seeing this phenomenon, then this location becomes exciting to be reviewed again using new methods and tools. There have been several studies relating to seismicity in this area, including observation of evidence of the Palu Koro fault as one of the faults in the Central Sulawesi region that are still active (Bellier et al. 2001; Pakpahan et al. 2015) studies on effects bathymetry in the Palu Bay when the tsunami hit this area in 2018 (Frederik et al. 2019), several studies of the source of the earthquake were mainly in the origin of faults and background earthquakes (McCaffrey and Sutardjo 1982; Stevens et al. 1999; Spencer 2011) and potential liquefaction and tsunami earthquake hazard (Baeda 2011; Sassa and Takagawa 2019). It appears from several studies above that no one has done a re-analysis of bedrock acceleration using the USGS PSHA and OpenQuake software, as will be done in this paper.

\section{Methods}

PSHA (Probabilistic Seismic Hazard Analysis) is an earthquake hazard calculation model that involves 3 (three) probabilities, namely the distance, magnitude, and acceleration probabilities that will be exceeded (Kramer 1996; Mulargia et al. 2016). These probability equations can be seen in Eq. (1). In this study, all of them will be calculated using USGS PSHA and OpenQuake software.

$$
[Y>y *]=\iint P[Y>y * \mid m, r] f_{M}(m) f_{R}(r) d m . d r
$$

$Y$ is the acceleration value, $y$ * is the exceeded acceleration threshold, $P$ is the probability, $m$ is the magnitude, and $r$ is the distance. As explained in the previous chapter, in the USGS PSHA software, there are three modules for calculating various earthquake sources. The subprograms are agridXnga and hazgridXnga to calculate shallow and deep background earthquake sources, fltrate, and hazFXnga to estimate fault sources faultSubXnga for megathrust earthquake source calculations. After everything has been calculated, it will be combined with the hazAll module (Petersen et al. 2008; Mueller et al. 2015). For more details, can be seen in Figure 2. In this paper, it has been mentioned that there are modifications in the form of GMPE additions to the module database, the additions made are BooreAtkinson2014, ChiouYoungs2014 and Campbell2014 (Boore et al. 2014; Campbell and Bozorgnia 2014; Chiou and Youngs 2014) for sources of background earthquakes and faults. The acquisition calculates the bedrock acceleration in Indonesian territory, as mentioned in the 2017 Indonesia Earthquake Hazard Map (PusGen 2017).

On the other hand, the OpenQuake analysis flow is more straightforward because it only fills in the input coordinates of the location to be analyzed, GMPE, logic tree, earthquake sources in one system, not to be 
separated as USGS PSHA. However, this software has another module that calculates what USGS PSHA cannot do, for example, risk calculation and deaggregation.

\subsection{DATA}

The data used in this study are the data used by the Indonesian earthquake team in making the 2017 earthquake map. This data covers deep, shallow, fault, and megathrust earthquake sources. The data is then processed using modified USGS and OpenQuake software. In the process, USGS PSHA was done on a temporary personal computer device for OpenQuake on the Pusgen Indonesia server.

Background data used in this study have been collected by the National Earthquake Study Center (PusGen) in the range of 1900-2016. A total of 51,855 earthquake data with magnitudes above $4.5 \mathrm{Mw}$ have been collected from several sources such as BMKG, Engdahl (Engdahl et al. 1998; Engdahl et al. 2007), International Seismic Center, NEIC-USGS. The data still contains foreshock and aftershock, so it needs to be sorted again to get the mainshock data only; this process is called declustering. With the declustering process, they leave only around 17,000 data with a depth of up to $300 \mathrm{~km}$. The declustering process is based on the time and distance windows method proposed by Gardner and Knopoff (Gardner and Knopoff 1974).

Meanwhile, sorting data based on completeness years adopted the method proposed by Stepp (Stepp 1972). In this method, the standard deviation between the time and earthquake rate comparison is calculated. If the standard deviation is no longer constant, then it is considered as the year of completeness (Nasir et al. 2013). Based on these methods, results are obtained for earthquakes with magnitudes between 4.5 and $6 \mathrm{Mw}$; the year limit used 1967, magnitude 6.0-7.0 $\mathrm{Mw}$ in 1957, and the magnitude above it in 1902. The fault source to be used is at a radius of $500 \mathrm{~km}$ from the boundary out of Central Sulawesi Province and presented in Table 1.

Table 1.Fault sources in the study area considering $500 \mathrm{~km}$ distance from the perimeter area 


\begin{tabular}{|c|c|c|c|c|c|c|c|}
\hline \multirow[t]{2}{*}{ I.D. } & \multicolumn{2}{|l|}{ Structure Name } & \multirow{2}{*}{$\begin{array}{l}\text { Sense } \\
\text { Mechanism }\end{array}$} & \multirow[t]{2}{*}{ Dip } & \multirow{2}{*}{$\begin{array}{l}\text { Max.Seg. } \\
\text { Length(km) }\end{array}$} & \multirow{2}{*}{$\begin{array}{l}\text { M } \\
\text { max }\end{array}$} & \multirow{2}{*}{$\begin{array}{l}\text { Slip Rate } \\
\text { mm/year }\end{array}$} \\
\hline & Main & Segment & & & & & \\
\hline 1 & Palukoro Fault & Makasar Strait & $\begin{array}{l}\text { Left-lateral } \\
\text { SS }\end{array}$ & 90 & 130 & 7.19 & 10 \\
\hline 2 & Palukoro Fault & Palu & $\begin{array}{l}\text { Left-lateral } \\
\text { SS }\end{array}$ & 90 & 31 & 6.81 & 10 \\
\hline 3 & Palukoro Fault & Saluki & $\begin{array}{l}\text { Left-lateral } \\
\text { SS }\end{array}$ & 90 & 44 & 6.99 & 10 \\
\hline 4 & Palukoro Fault & Moa & $\begin{array}{l}\text { Left-lateral } \\
\text { SS }\end{array}$ & 90 & 66 & 7.19 & 10 \\
\hline 5 & Matano Fault & Kuleana & $\begin{array}{l}\text { Left-lateral } \\
\text { SS }\end{array}$ & 90 & 22 & 6.63 & 7 \\
\hline 6 & Matano Fault & Pewusai & Revese & $45 N$ & 46 & 7.01 & 7 \\
\hline 7 & Matano Fault & Matano & $\begin{array}{l}\text { Left-lateral } \\
\text { SS }\end{array}$ & 90 & 35 & 6.87 & 7 \\
\hline 8 & Matano Fault & Pamsoa & $\begin{array}{l}\text { Left-lateral } \\
\text { SS }\end{array}$ & 90 & 44 & 6.98 & 7 \\
\hline 9 & Matano Fault & Ballawai & $\begin{array}{l}\text { Left-lateral } \\
\text { SS }\end{array}$ & 90 & 26 & 6.72 & 7 \\
\hline 10 & Matano Fault & Geressa & $\begin{array}{l}\text { Left-lateral } \\
\text { SS }\end{array}$ & 91 & 80 & 7.28 & 7 \\
\hline 11 & $\begin{array}{l}\text { Soroako } \\
\text { Thrust }\end{array}$ & $A$ & Reverse & $45 \mathrm{E}$ & 24 & 6.68 & 0.1 \\
\hline 12 & $\begin{array}{l}\text { Soroako } \\
\text { Thrust }\end{array}$ & B & Reverse & $45 \mathrm{E}$ & 20 & 6.59 & 0.1 \\
\hline 13 & $\begin{array}{l}\text { Soroako } \\
\text { Thrust }\end{array}$ & C & Reverse & $45 \mathrm{E}$ & 16 & 6.49 & 0.1 \\
\hline 14 & Batui Thrust & & Revese & 45SE & 84 & 7.37 & 1 \\
\hline 15 & Balantak & & $\begin{array}{l}\text { Right-lateral } \\
\text { SS }\end{array}$ & 90 & 149 & 7.60 & 0.5 \\
\hline 16 & $\begin{array}{l}\text { Makasar Strait } \\
\text { Thrust }\end{array}$ & North & Reverse & $45 \mathrm{E}$ & 100 & 7.12 & 2 \\
\hline 17 & $\begin{array}{l}\text { Makasar Strait } \\
\text { Thrust }\end{array}$ & Central & Reverse & $45 \mathrm{E}$ & 170 & 7.38 & 2 \\
\hline 18 & $\begin{array}{l}\text { Makasar Strait } \\
\text { Thrust }\end{array}$ & Mamuju & Reverse & $45 \mathrm{E}$ & 40 & 7.02 & 2 \\
\hline 19 & $\begin{array}{l}\text { Makasar Strait } \\
\text { Thrust }\end{array}$ & Somba & Reverse & $45 \mathrm{E}$ & 80 & 7.35 & 2 \\
\hline
\end{tabular}




\begin{tabular}{|c|c|c|c|c|c|c|c|}
\hline \multirow[t]{2}{*}{ I.D. } & \multicolumn{2}{|c|}{ Structure Name } & \multirow{2}{*}{$\begin{array}{l}\text { Sense } \\
\text { Mechanism }\end{array}$} & \multirow[t]{2}{*}{ Dip } & \multirow{2}{*}{$\begin{array}{l}\text { Max.Seg. } \\
\text { Length(km) }\end{array}$} & \multirow{2}{*}{$\begin{array}{l}\text { max } \\
\text { Max }\end{array}$} & \multirow{2}{*}{$\begin{array}{l}\text { Slip Rate } \\
\text { mm/year }\end{array}$} \\
\hline & Main & Segment & & & & & \\
\hline 20 & Buton & B & SS & 90 & 60 & 7.14 & 0.1 \\
\hline 21 & Peleng & & SS & 90 & 44 & 6.98 & 1 \\
\hline 22 & Ambelang & & Revese & 45 & 50 & 7.04 & 1 \\
\hline 23 & Sausu & & SS & 90 & 31 & 6.81 & 1 \\
\hline 24 & Tokararu & & Revese & 45 & 80 & 7.26 & 2 \\
\hline 25 & Poso & & Reverse & $45 \mathrm{E}$ & 85 & 7.38 & 0.1 \\
\hline 26 & Loa & & SS & 90 & 86 & 7.32 & 0.1 \\
\hline 27 & Weluki & & Reverse & $45 \mathrm{~W}$ & 72 & 7.30 & 0.1 \\
\hline 28 & Tomini & & Revese & 45 & 59 & 7.12 & 0.1 \\
\hline 29 & Lawanopo & & SS & 90 & 130 & 7.00 & 0.1 \\
\hline 30 & Tolo Thrust & & Revese & $45 W$ & 120 & 7.00 & 1 \\
\hline 31 & Gorontalo & North & Strikeslip & 90 & 74 & 6.90 & 1 \\
\hline 32 & Gorontalo & South & Strikeslip & 90 & 70 & 6.87 & 1 \\
\hline 33 & Walanae & & Strikeslip & 90 & 130 & 7.00 & 0.5 \\
\hline 34 & Kendari Fault & North & unknown & 90 & 24 & 6.50 & 0.1 \\
\hline 35 & Tarakan & & S.S. & & 206 & 7.41 & 0.1 \\
\hline 36 & Maleei & & Reverse & $45 \mathrm{E}$ & 70 & 7.00 & 0.1 \\
\hline 37 & East Balantak & & $\begin{array}{l}\text { Strikeslip } \\
\text { sinistral }\end{array}$ & 90 & 68 & 7.20 & 15 \\
\hline 38 & $\begin{array}{l}\text { South } \\
\text { Balantak }\end{array}$ & $\begin{array}{l}\text { South } \\
\text { Balantak }\end{array}$ & $\begin{array}{l}\text { Strikeslip } \\
\text { sinistral }\end{array}$ & 90 & 53 & 7.10 & 15 \\
\hline 39 & North Sula & North Sula & Thrust & $45 S$ & 405 & 8.10 & 20 \\
\hline 40 & Sula Fault & Kano & $\begin{array}{l}\text { Strikeslip } \\
\text { sinistral }\end{array}$ & 90 & 32 & 6.50 & 15 \\
\hline 41 & Sula Fault & Talibu & $\begin{array}{l}\text { Strikeslip } \\
\text { sinistral }\end{array}$ & 90 & 62 & 7.20 & 15 \\
\hline 42 & Sula Fault & Mangole & $\begin{array}{l}\text { Strikeslip } \\
\text { sinistral }\end{array}$ & 90 & 159 & 7.60 & 15 \\
\hline 43 & Sorong Fault & $\begin{array}{l}4 \text { South } \\
\text { Halmahera }\end{array}$ & $\begin{array}{l}\text { Strikeslip } \\
\text { sinistral }\end{array}$ & 60 & 258 & 7.90 & 15 \\
\hline
\end{tabular}




\begin{tabular}{|c|c|c|c|c|c|c|c|}
\hline \multirow[t]{2}{*}{ I.D. } & \multicolumn{2}{|l|}{ Structure Name } & \multirow{2}{*}{$\begin{array}{l}\text { Sense } \\
\text { Mechanism }\end{array}$} & \multirow[t]{2}{*}{ Dip } & \multirow{2}{*}{$\begin{array}{l}\text { Max.Seg. } \\
\text { Length(km) }\end{array}$} & \multirow{2}{*}{$\begin{array}{l}\text { M } \\
\text { max }\end{array}$} & \multirow{2}{*}{$\begin{array}{l}\text { Slip Rate } \\
\text { mm/year }\end{array}$} \\
\hline & Main & Segment & & & & & \\
\hline 44 & Sorong Fault & 1 Obi & $\begin{array}{l}\text { Strikeslip } \\
\text { sinistral }\end{array}$ & 90 & 137 & 7.60 & 10 \\
\hline 45 & Sorong Fault & 2 Obi-Kofiau & $\begin{array}{l}\text { Strikeslip } \\
\text { sinistral }\end{array}$ & 90 & 191 & 7.40 & 12.5 \\
\hline 46 & Seram FTB & 1 West & Thrust & $45 S W$ & 514 & 8.20 & 15 \\
\hline 47 & North Buru & & Strikeslip & 90 & 206 & 7.40 & 0.5 \\
\hline 48 & Manipa & & Strikeslip & 90 & 100 & 7.40 & 0.5 \\
\hline 49 & South Buru & 2 & Strikeslip & 90 & 91 & 7.00 & 0.5 \\
\hline 50 & $\begin{array}{l}\text { Flores Backarc } \\
\text { Thrust }\end{array}$ & Wetar & Reverse & $45 S$ & 216 & 7.50 & 18.3 \\
\hline 51 & $\begin{array}{l}\text { Flores Backarc } \\
\text { Thrust }\end{array}$ & $\begin{array}{l}\text { Nusa } \\
\text { Tenggara } \\
\text { Timur }\end{array}$ & Reverse & $45 S$ & 236 & 7.50 & 5.6 \\
\hline 52 & $\begin{array}{l}\text { Flores Backarc } \\
\text { Thrust }\end{array}$ & $\begin{array}{l}\text { Nusa } \\
\text { Tenggara } \\
\text { Tengah }\end{array}$ & Reverse & $45 S$ & 173 & 7.40 & 11.6 \\
\hline 53 & Selayar & East & Normal & $60 \mathrm{~W}$ & 167 & 7.2 & 0.5 \\
\hline 54 & Selayar & west & Normal & $60 \mathrm{E}$ & 152 & 7.2 & 0.5 \\
\hline 55 & $\begin{array}{l}\text { Flores Backarc } \\
\text { Thrust }\end{array}$ & $\begin{array}{l}\text { Lombok } \\
\text { Sumbawa }\end{array}$ & Reverse & $45 N$ & 310 & 8.00 & 9.9 \\
\hline 56 & $\begin{array}{l}\text { Flores Backarc } \\
\text { Thrust }\end{array}$ & Bali & Reverse & $45 N$ & 84 & 7.40 & 7 \\
\hline 57 & Lombok Strait & North & Strikeslip & 90 & 156 & 7.60 & 0.5 \\
\hline 58 & RMKS & East & Strikeslip & 90 & 230 & 7.80 & 1.5 \\
\hline 59 & RMKS & West & Strikeslip & 90 & 258 & 7.90 & 1.5 \\
\hline 60 & Bawean & & Strikeslip & 90 & 156 & 7.60 & 0.5 \\
\hline 61 & Meratus & & Reverse & $45 \mathrm{~W}$ & 105 & 7 & 0.2 \\
\hline 62 & Mangkalihat & & Strikeslip & 90 & 111 & 7 & 0.5 \\
\hline 63 & $\begin{array}{l}\text { Tarakan- } \\
\text { Kalimantan }\end{array}$ & & Strikeslip & 90 & 100 & 7 & 0.3 \\
\hline
\end{tabular}


The megathrust subduction source analyzed is also considered a perimeter of $500 \mathrm{~km}$ from the study area (Figure 3). The subduction area contains only an earthquake source with a maximum depth of 50 $\mathrm{km}$, which is deeper than that of the background source.

\subsection{LOGIC TREE}

This study involves a comparison of weight analysis as done in making the 2017 Indonesia Earthquake map. The logic tree for the USGS PSHA can be seen in Figure 4. On the other hand, analysis using OpenQuake can be seen in Table 2 below. It is understood that there is a difference in GMPE that is used for reasons when making the 2017 Indonesia Earthquake map, OpenQuake already has a newer database while USGS PSHA has not. For this reason, this study tried to modify the USGS PSHA by updating it as used in GMPE on the 2017 Indonesia Earthquake map, which is updating in fault and shallow background GMPE, i.e., Boore Atkinson 2014, Campbel Bozorgnia 2014 and Chiou Young 2014. The expert's engineering judgment considers the weight proportion used in OpenQuake and USGS PSHA. It concludes that specific GMPE is suitable or not to be applied in the Indonesia region.

Table 2.Logic tree GMPE in OpenQuake 


\begin{tabular}{|c|c|c|}
\hline Seismic Sources & Attenuation Functions & Ratio \\
\hline \multirow{6}{*}{$\begin{array}{l}\text { Shallow crustal fault and shallow } \\
\text { background sources }\end{array}$} & BooreAtkinson2008 & 0.2 \\
\hline & CampbellBozorgnia2008 & 0.2 \\
\hline & ChiouYoungs2008 & 0.2 \\
\hline & Boore-Atkinson NGA West-2 2014 & 0.133 \\
\hline & Campbell-Bozorgnia NGA West-2, 2014 & 0.133 \\
\hline & Chiou-Young NGA West-2, 2014 & 0.134 \\
\hline \multirow[t]{4}{*}{ Megathrust (interslab zone) sources } & AtkinsonBoore1995GSCBest & 0.15 \\
\hline & ZhaoEtAl2006Sinter & 0.30 \\
\hline & Youngs et al., 1997 & 0.15 \\
\hline & Abrahamson et al., 2015 (BC Hydro) & 0.40 \\
\hline \multirow{6}{*}{$\begin{array}{l}\text { Deep background (Intraslab Benioff zone) } \\
\text { sources }\end{array}$} & Atkinson-Boore, 2003 & 0.34 \\
\hline & $\begin{array}{l}\text { (AB Intraslab seismicity Cascadia region BC- } \\
\text { rock condition) }\end{array}$ & \\
\hline & Youngs et al., 1997 & 0.33 \\
\hline & (Geomatrix slab seismicity rock) & \\
\hline & Atkinson-Boore, 2003 & 0.33 \\
\hline & $\begin{array}{l}\text { (Intraslab seismicity worldwide data region BC- } \\
\text { rock condition) }\end{array}$ & \\
\hline
\end{tabular}

\section{Results And Discussion}

Based on the calculation using a software logic tree by USGS PSHA modifications and OpenQuake, the obtained results as presented in Figure 5 a-e. While analysis using the combined weighting of USGS PSHA OpenQuake by 6: 4 is shown in Figure 5f. PSHA calculations using background sources (Figure 5a) show a pattern leading to a fault source. As is known, that a background earthquake source is an event that has a record earthquake magnitude between 4.5-6.4 Mw, seismic source unknown mechanism, so that there may be the possibility of an earthquake originating from diverse sources. In this study, it is known that shallow background sources using OpenQuake (Figure 5a left) produce a zone with a PGA magnitude of $0.4-0.5 \mathrm{~g}$ in the central part of Central Sulawesi Province, part of the eastern edge of the coast, zone $0.25-0.3 \mathrm{~g}$ on the south side and a small island around this province. In addition to these zones, this area is dominated by an area with a PGA magnitude of $0.3-0.4 \mathrm{~g}$.

On the other hand, the analysis uses a modified USGS (Figure 5a right), resulting in an area with a higher $0.25-0.3 \mathrm{~g}$ zone on the south coast of the province. The suspects of this result are the Batui Fault's 
presence in the eastern region of the area. The analysis of seismic sources in the background (Figure $5 \mathrm{~b}$ left and right) was the second of this software producing similar zoning. The difference is in the province's southeast area, where USGS PSHA has zone 0.5 -0.6 g, while analysis using OpenQuake does not create it. Besides that, on the north side, USGS PSHA produced an overall zone of $0.4-0.5 \mathrm{~g}$ while OpenQuake still left part of the region with a value of $0.3-0.4 \mathrm{~g}$. This analysis's most extreme case is shown in the report using the seismic source fault (Figure $5 \mathrm{c}$ left and right).

OpenQuake shows the zone around the fault is not too large the PGA value (maximum around 1.2g), while with USGS PSHA shows a higher amount up to $1.8 \mathrm{~g}$. In another case, the megathrust earthquake source showed no significant zoning differences in the two analyses (Figure $5 \mathrm{~d}$ left and right). What can be observed here is that the USGS PSHA produces a lower zone on the south side while on the north side, the value is higher. The overall value of acceleration present in both analyses makes OpenQuake generate a maximum value lower than the USGS PSHA modification, i.e., $1.2 \mathrm{~g}$ to OpenQuake and $1.8 \mathrm{~g}$ for USGS PSHA. A comparison of all earthquake sources with the two analyses can be seen in Figure $5 e$ (left and right). The most apparent difference using both software in calculating hazard from fault source is a zone on both the southwest and east of the province.

Based on the Pusgen book (PusGen, 2017), the results of maps used nationally are a combination of USGS PSHA and OpenQuake analysis. In this study, a weighting ratio of 6: 4 was made for USGS PSHA: OpenQuake. The results of this combination can be seen in Figure 6. In the figure, it produces a zone between 0.3-1. 6 g. Compared with the 2017 Indonesia Earthquake Map (Figure 7), this study's results create a higher value in the central area of Central Sulawesi Province, namely by an increase in the 0.6$0.7 \mathrm{~g}$ zone. This phenomenon is suspected using newer GMPE to produce a significant acceleration in the region around the fault.

\section{Conclusion}

In this study, the following conclusions are drawn, the PGA value in bedrock when 2475 years ( $2 \%$ exceeded 50 years) obtained by the attenuation development of USGS PSHA and OpenQuake software cannot be directly compared with National Hazard Map Indonesia 2017. This is because the existing Indonesian Earthquake Map combines two software, namely OpenQuake and USGS PSHA, with a weight ratio of 4:6 with the USGS PSHA GMPE records still using 2008 version. PSHA USGS software modifications, when compared directly with OpenQuake, will produce PGA higher value. A high value is more dominant due to the existence of fault on the central and eastern province of Central Sulawesi, namely Fault Batui. In the combination analysis conducted at the end of this study, the acceleration range values are the same as the Indonesian Earthquake Map 2017. Still, they have different zonation patterns in the central part of Central Sulawesi Province, where there is an enlarged zone of $0.6-0.7 \mathrm{~g}$.

\section{List Of Abbreviations}


USGS PSHA = United States Geological Survey Probabilistic Seismic Hazard Analysis; an earthquake analysis software

GMPE = Ground Motion Prediction Analysis; an equation that provides a means of predicting the level of ground shaking and its associated uncertainty at any given site or location, based on an earthquake magnitude, source-to-site distance, local soil conditions, fault mechanism, etc

PSHA = Probabilistic Seismic Hazard Analysis; an approach to calculating an earthquake hazard by considering the probability of magnitude, distance, and acceleration exceeding a certain acceleration limit or specific return periods

PusGen = Pusat Studi Gempa Nasional (ind)/ National Earthquake Study Center; an institution engaged in earthquake studies on a national scale under supervision of Ministry of Public Works and Public Housing

NEIC-USGS = National Earthquake Information Center- United States Geological Survey; a part of the Department of the Interior, United States Geological Survey which coordinated the collection of seismological data in the United States

SS = Strike-Slip; mechanism of fault which has horizontal movement following the fault axis direction

NGA = Next Generation Attenuation; one study results from several institutions coordinated by the Pacific Engineering Research Center (PEER), USGS, and the Southern California Earthquake Center, aiming to make attenuation more comprehensive than the previous year (before 2007). After this attenuation, the developed one is well known as NGA West-2 (begin with 2014)

\section{Declarations}

The data that support the findings of this study are available from PusGen (Indonesian National Earthquake Study Center). Still, restrictions apply to the availability of these data, which were used under license for the current study, and so are not publicly available. Data are, however, available from the authors upon reasonable request and with permission of PusGen. The authors declare that we have no competing interests. AJS and DDA analyzed bedrock peak ground acceleration using OpenQuake and USGS PSHA modification. AMS and OFS performed the mapping and GIS process of bedrock acceleration, while $\mathrm{MI}, \mathrm{H}$, and $\mathrm{MA}$ were a major contributor overall, analyzing and providing the manuscript's data. All authors read and approved the final manuscript.

\section{References}

1. Baeda, Achmad Yasir. 2011. Seismic and tsunami hazard potential in Sulawesi Island, Indonesia. Journal of International Development and Cooperation 17: 17-30. 
2. Bellier, Olivier, Michel Sébrier, Thierry Beaudouin, Michel Villeneuve, Regis Braucher, Didier Bourles, Lionel Siame, Eka Putranto, and Indyo Pratomo. 2001. High slip rate for a low seismicity along the Palu-Koro active fault in central Sulawesi (Indonesia). Terra Nova 13: 463-470.

3. Boore, David M, Jonathan P Stewart, Emel Seyhan, and Gail M Atkinson. 2014. NGA-West2 equations for predicting PGA, PGV, and 5\% damped PSA for shallow crustal earthquakes. Earthquake Spectra 30: $1057-1085$.

4. Campbell, Kenneth $W$, and Yousef Bozorgnia. 2014. NGA-West2 ground motion model for the average horizontal components of PGA, PGV, and 5\% damped linear acceleration response spectra. Earthquake Spectra 30: 1087-1115.

5. Chiou, Brian S-J, and Robert R Youngs. 2014. Update of the Chiou and Youngs NGA model for the average horizontal component of peak ground motion and response spectra. Earthquake Spectra 30: 1117-1153.

6. Engdahl, E Robert, Rob van der Hilst, and Raymond Buland. 1998. Global teleseismic earthquake relocation with improved travel times and procedures for depth determination. Bulletin of the Seismological Society of America 88: 722-743.

7. Engdahl, E Robert, Antonio Villasenor, Heather R DeShon, and Clifford H Thurber. 2007. Teleseismic relocation and assessment of seismicity (1918-2005) in the region of the $2004 \mathrm{M} \mathrm{w} 9.0$ SumatraAndaman and $2005 \mathrm{M}$ w 8.6 Nias Island great earthquakes. Bulletin of the Seismological Society of America 97: S43-S61.

8. Faris, Fikri, and Wang Fawu. 2014. Investigation of the initiation mechanism of an earthquakeinduced landslide during rainfall: a case study of the Tandikat landslide, West Sumatra, Indonesia. Geoenvironmental Disasters 1. Springer: 4.

9. Field, Edward H, Thomas H Jordan, and C Allin Cornell. 2003. OpenSHA: A developing communitymodeling environment for seismic hazard analysis. Seismological Research Letters 74: 406-695.

10. Frederik, Marina CG, Ramadhan Adhitama, Nugroho D Hananto, Shahab Sahabuddin, Muhammad Irfan, Omar Moefti, Dimas B Putra, and Bondan F Riyalda. 2019. First results of a bathymetric survey of palu bay, central sulawesi, indonesia following the tsunamigenic earthquake of 28 september 2018. Pure and Applied Geophysics 176: 3277-3290.

11. Gardner, JK, and Leon Knopoff. 1974. Is the sequence of earthquakes in Southern California, with aftershocks removed, Poissonian? Bulletin of the Seismological Society of America 64: 1363-1367.

12. GEM. 2016. The OpenQuake-engine User Manual. Global Earthquake Model (GEM) Technical Report 2016-06: 193. https://doi.org/10.13117/GEM.OPENQUAKE.MAN.ENGINE.2.0/01.

13. Irsyam, Masyhur, Phil R Cummins, M Asrurifak, Lutfi Faizal, Danny Hilman Natawidjaja, Sri Widiyantoro, Irwan Meilano, et al. 2020. Development of the 2017 national seismic hazard maps of Indonesia. Earthquake Spectra I. SAGE Publications Sage UK: London, England: 25. https://doi.org/10.1177/8755293020951206.

14. Kara, Emel KIZILOK, and Kübra Durukan. 2017. The Statistical Analysis of the Earthquake Hazard for Turkey by Generalized Linear Models. Gazi University Journal of Science 30: 584-597. 
15. Kramer, Steven L. 1996. Geotechnical Earthquake Engineering. United State of America: Prentice Hall.

16. McCaffrey, R, and R Sutardjo. 1982. Reconnaissance microearthquake survey of Sulawesi, Indonesia. Geophysical Research Letters 9: 793-796.

17. McCaffrey, Robert. 2009. The Tectonic Framework of the Sumatran Subduction Zone. Annual Review of Earth and Planetary Sciences 9: 24. https://doi.org/10.1146/annurev.earth.031208.100212.

18. Mueller, Charles S, Richard W Briggs, Robert L Wesson, and Mark D Petersen. 2015. Updating the USGS seismic hazard maps for Alaska. Quaternary Science Reviews 113: 39-47.

19. Mulargia, Francesco, Philip B Stark, and Robert J Geller. 2016. Why is Probabilistic Seismic Hazard Analysis (PSHA) still used? Physics of the Earth and Planetary Interiors 264 (2017): 13.

20. Nasir, Asma, Wolfgang Lenhardt, Esther Hintersberger, and Kurt Decker. 2013. Assessing the completeness of historical and instrumental earthquake data in Austria and the surrounding areas. Austrian Journal of Earth Sciences 106/1: 13.

21. Natawidjaja, Danny Hilman, Kyle Bradley, Mudrik R Daryono, Sonny Aribowo, and Jason Herrin. 2017. Late Quaternary eruption of the Ranau Caldera and new geological slip rates of the Sumatran Fault Zone in Southern Sumatra, Indonesia. Geoscience Letters 4: 21.

22. Pagani, M, D Monelli, G Weatherill, L Danciu, H Crowley, V Silva, P Henshaw, L Butler, M Nastasi, and L Panzeri. 2014. OpenQuake engine: an open hazard (and risk) software for the global earthquake model. Seismological Research Letters 85: 692-702.

23. Pakpahan, Suliyanti, Drajat Ngadmanto, Masturyono Masturyono, Supriyanto Rohadi, Rasmid Rasmid, Handi Sulistyo Widodo, and Pupung Susilanto. 2015. Analisis Kegempaan di Zona Sesar Palu Koro, Sulawesi Tengah. Jurnal Lingkungan dan Bencana Geologi 6: 253-264.

24. Petersen, M D, A D Frankel, S C Harmsen, C S Mueller, R L Wheeler, R L Wesson, Y Yzeng, et al. 2008. Documentation for the 2008 Update of the United States National Seismic Hazard Maps. Open File Report 2008-1128. U.S. Department of the Interior, U.S. Geological Survey.

25. PusGen. 2017. Peta Sumber dan Bahaya Gempa Indonesia Tahun 2017. 1st ed. Bandung: Puslitbang Perumahan dan Pemukiman.

26. Sassa, Shinji, and Tomohiro Takagawa. 2019. Liquefied gravity flow-induced tsunami: first evidence and comparison from the 2018 Indonesia Sulawesi earthquake and tsunami disasters. Landslides 16: 195-200.

27. Setiyono, Urip, Indra Gunawan, Priyobudi Priyobudi, Tatok Yatimantoro, Rudi Teguh Imananta, Mohamad Ramdhan, Hidayanti Hidayanti, et al. 2019. Katalog Gempabumi Signifikan dan Merusak Tahun 1821-2018. Pusat Gempabumi dan Tsunami Kedeputian Bidang Geofisika Badan Meteorologi Klimatologi dan Geofisika.

28. Silva, V, H Crowley, C Yepes, and R Pinho. 2014. Presentation of the OpenQuake-engine, an open source software for seismic hazard and risk assessment. In Proceedings of the 10th U.S. National conference on earthquake engineering, Anchorage, Alaska.

29. Spencer, Jon E. 2011. Gently dipping normal faults identified with Space Shuttle radar topography data in central Sulawesi, Indonesia, and some implications for fault mechanics. Earth and Planetary 
Science Letters 308: 267-276.

30. Stepp, J C. 1972. Analysis of completeness of the earthquake sample in the Puget Sound area and its effect on statistical estimates of earthquake hazard. In Proc. of the $1 \mathrm{st}$ Int. Conf. on Microzonazion, Seattle, 2:897-910.

31. Stevens, C, R McCaffrey, Y Bock, J Genrich, C Subarya, SSO Puntodewo, and C Vigny. 1999. Rapid rotations about a vertical axis in a collisional setting revealed by the Palu fault, Sulawesi, Indonesia. Geophysical Research Letters 26: 2677-2680.

32. Syahbana, Arifan Jaya, Garup Lambang Goro, Okta Fajar Saputra, Dega Damara Aditramulyadi, Masyhur Irsyam, M Asrurifak, and Hendriyawan Hendriyawan. 2020. Application of Modified PSHA USGS Software in Java Island Bed Rock Peak Ground Acceleration and Hazard Curve with 2475 Years Return Period. International Journal of Advanced Science and Technology 29: 3138-3148.

\section{Figures}




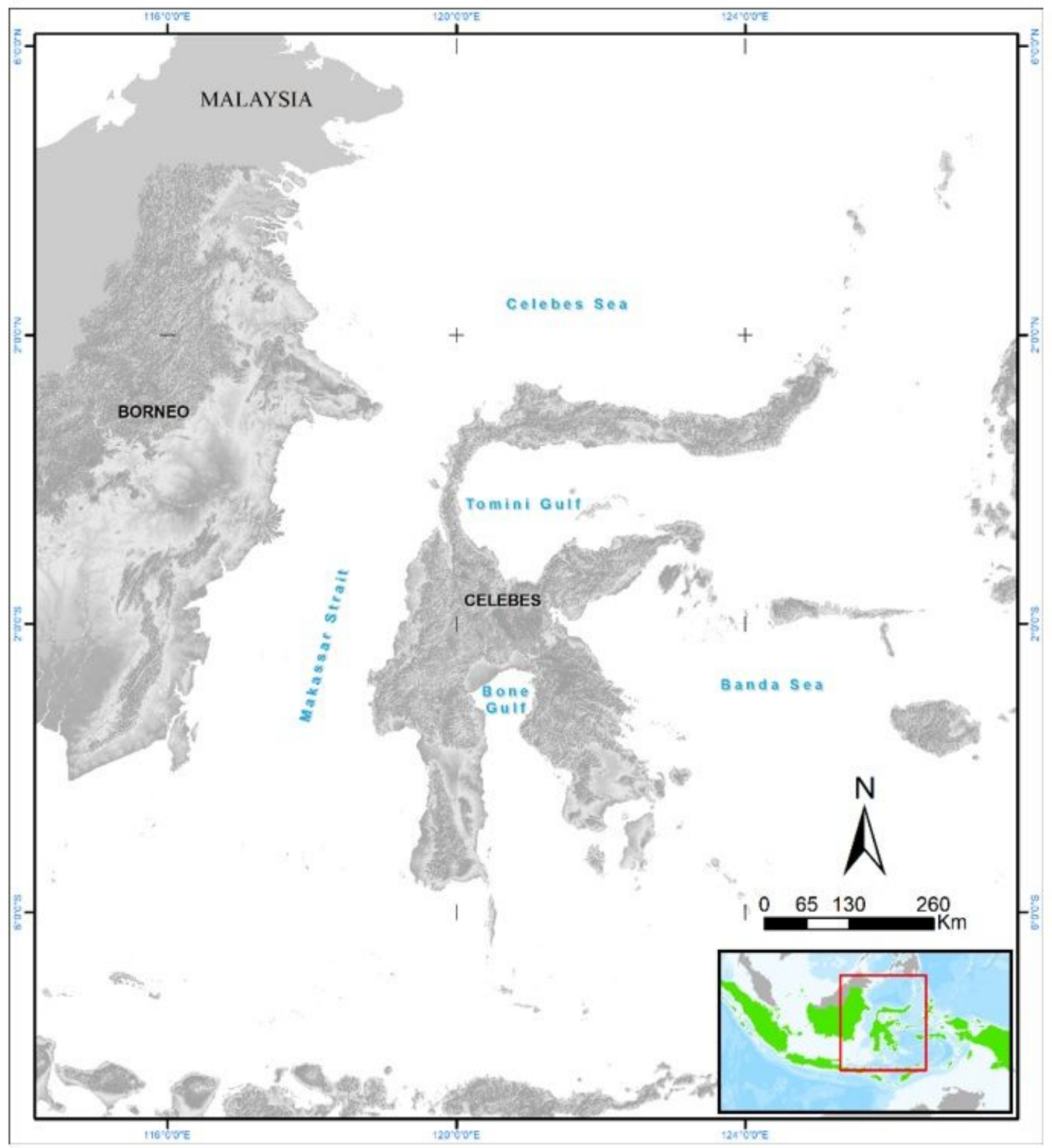

Figure 1

Location of the study, Central Sulawesi Province, Indonesia. Note: The designations employed and the presentation of the material on this map do not imply the expression of any opinion whatsoever on the part of Research Square concerning the legal status of any country, territory, city or area or of its authorities, or concerning the delimitation of its frontiers or boundaries. This map has been provided by the authors. 


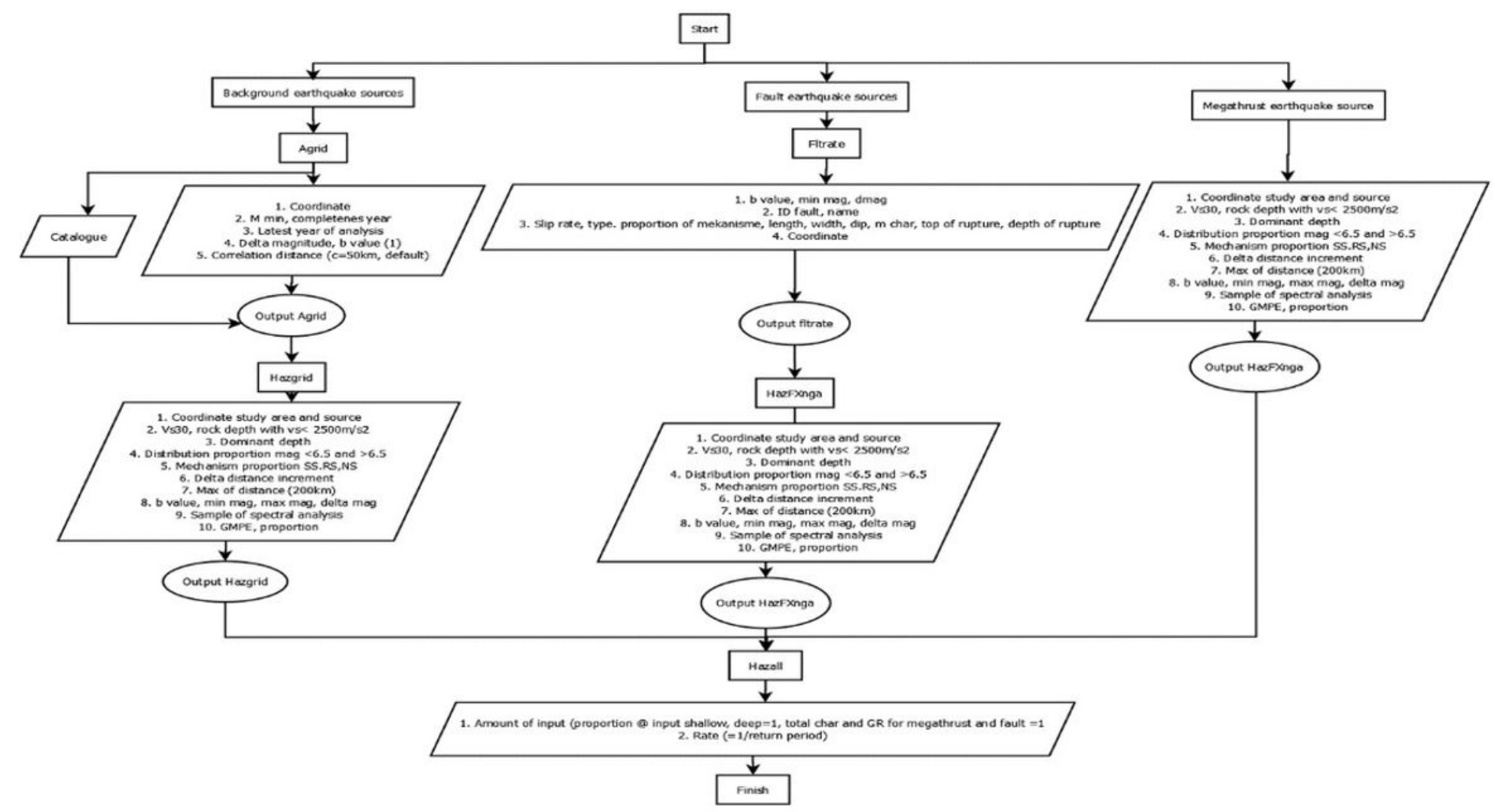

Figure 2

The flow of the analysis procedure using USGS PSHA modification 

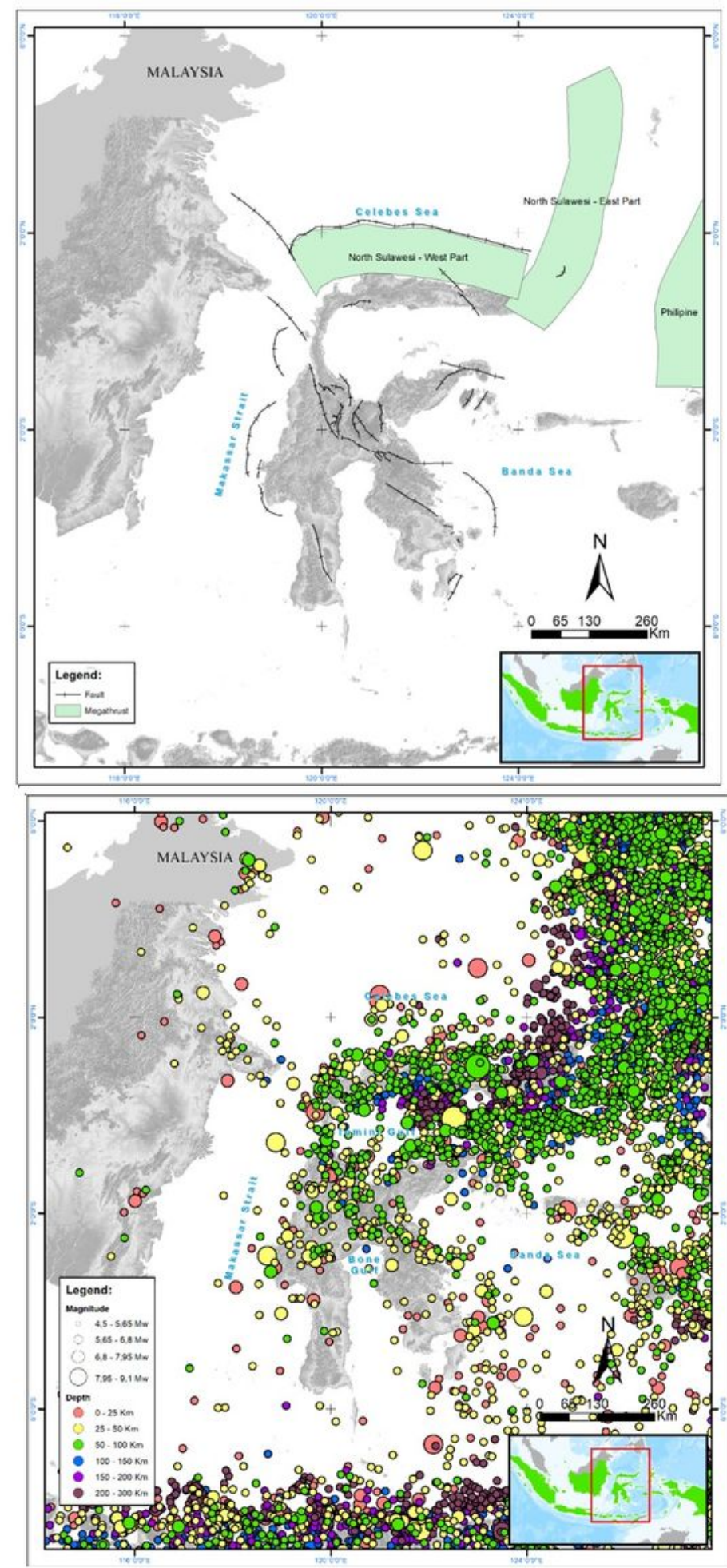

\section{Figure 3}

Seismotectonic of fault and subduction (megathrust) around Central Sulawesi (above) and background source earthquake (bellow). Note: The designations employed and the presentation of the material on this map do not imply the expression of any opinion whatsoever on the part of Research Square concerning the legal status of any country, territory, city or area or of its authorities, or concerning the delimitation of its frontiers or boundaries. This map has been provided by the authors. 

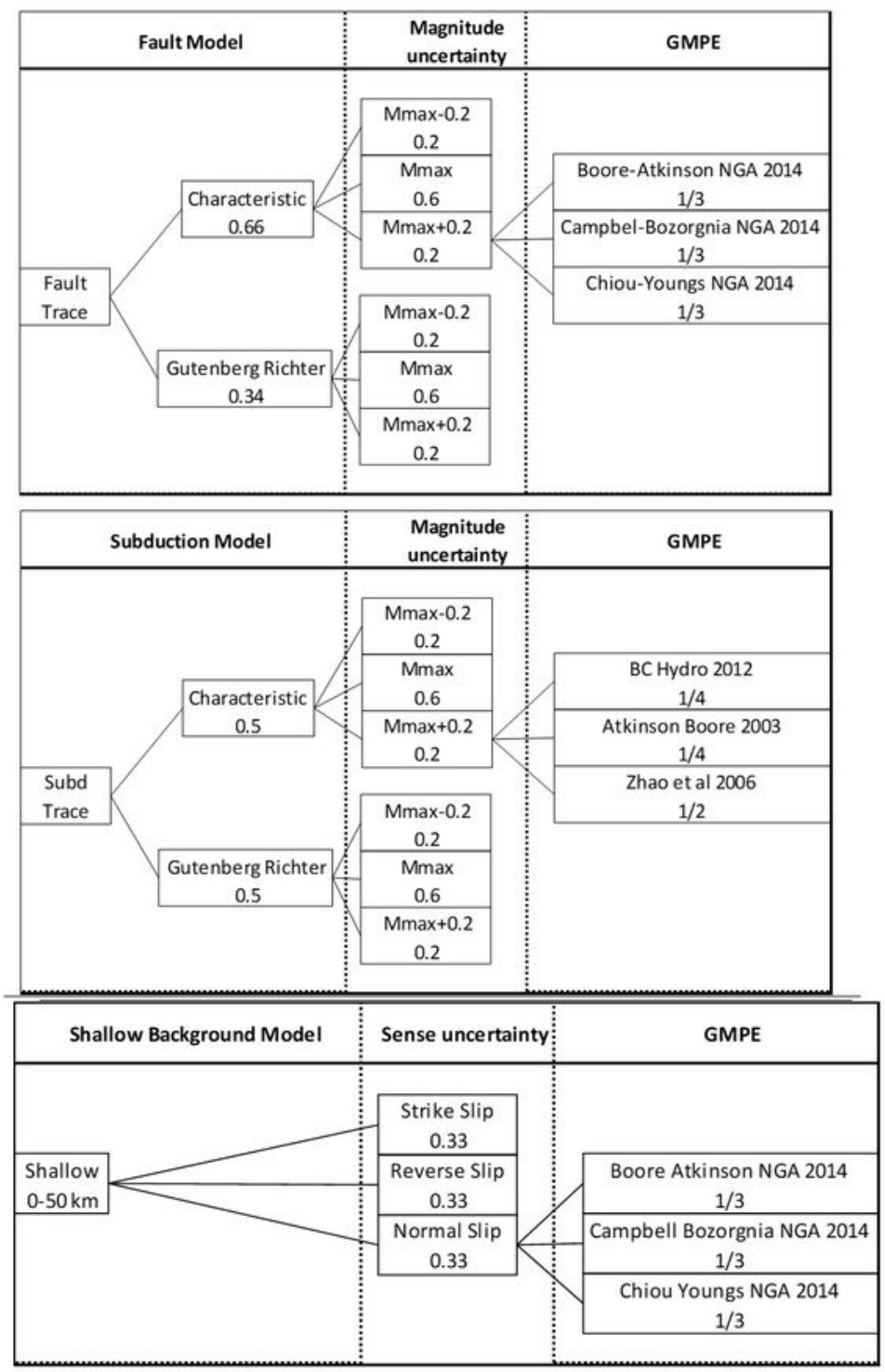

\begin{tabular}{|c|c|c|}
\hline Deep Background Model & Sense uncertainty & GMPE \\
\hline & $\begin{array}{c}\text { Strike Slip } \\
0.33\end{array}$ & \\
\hline \multirow{4}{*}{$50-300 \mathrm{~km}$} & Reverse Slip & $A B$ intraslab $B C$ rock \\
\hline & 0.33 & $1 / 3$ \\
\hline & Normal Slip & $\begin{array}{l}\text { Geomatrix slab } 1997 \\
1 / 3\end{array}$ \\
\hline & & $\begin{array}{c}\text { AB } 2003 \text { intraslab world } \\
\text { data BC rock } \\
1 / 3\end{array}$ \\
\hline
\end{tabular}

\section{Figure 4}

\section{Logic tree GMPE USGS PSHA}



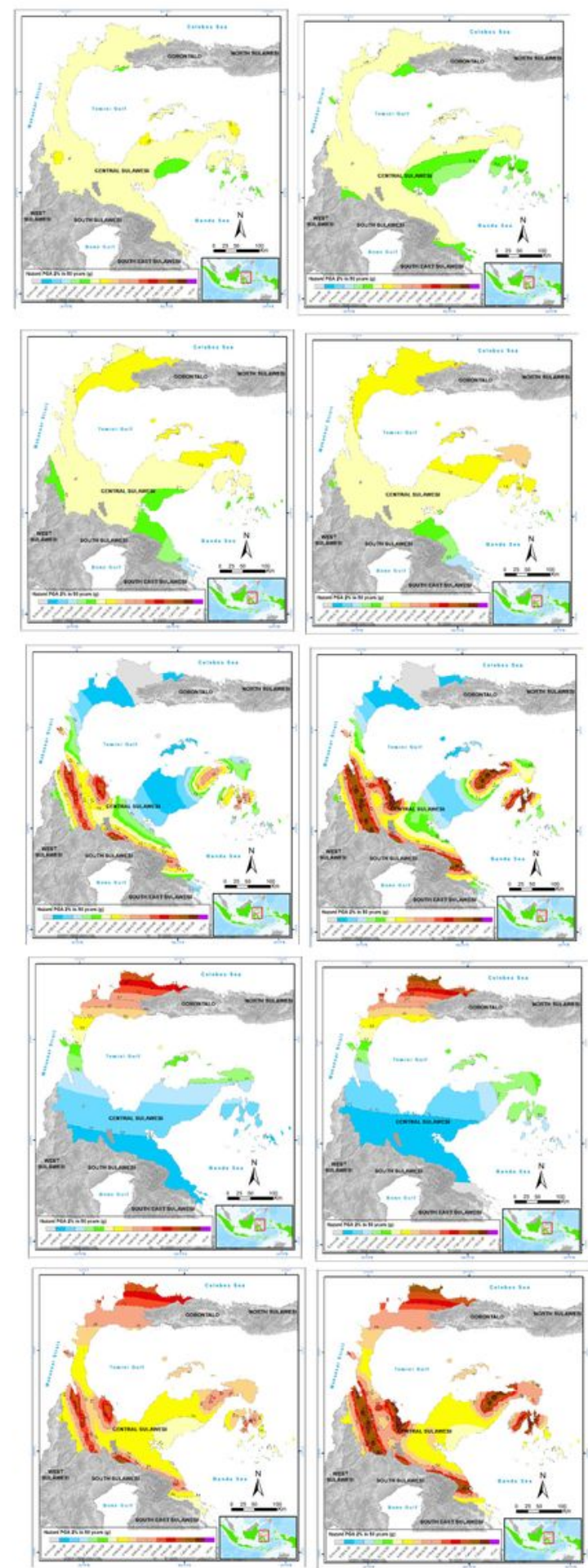

\section{Figure 5}

Comparison PGA 2475 years return period OpenQuake left, right USGS a) background shallow, b) deep background, c) fault, d) megathrust, e) all source Note: The designations employed and the presentation of the material on this map do not imply the expression of any opinion whatsoever on the part of Research Square concerning the legal status of any country, territory, city or area or of its authorities, or concerning the delimitation of its frontiers or boundaries. This map has been provided by the authors. 


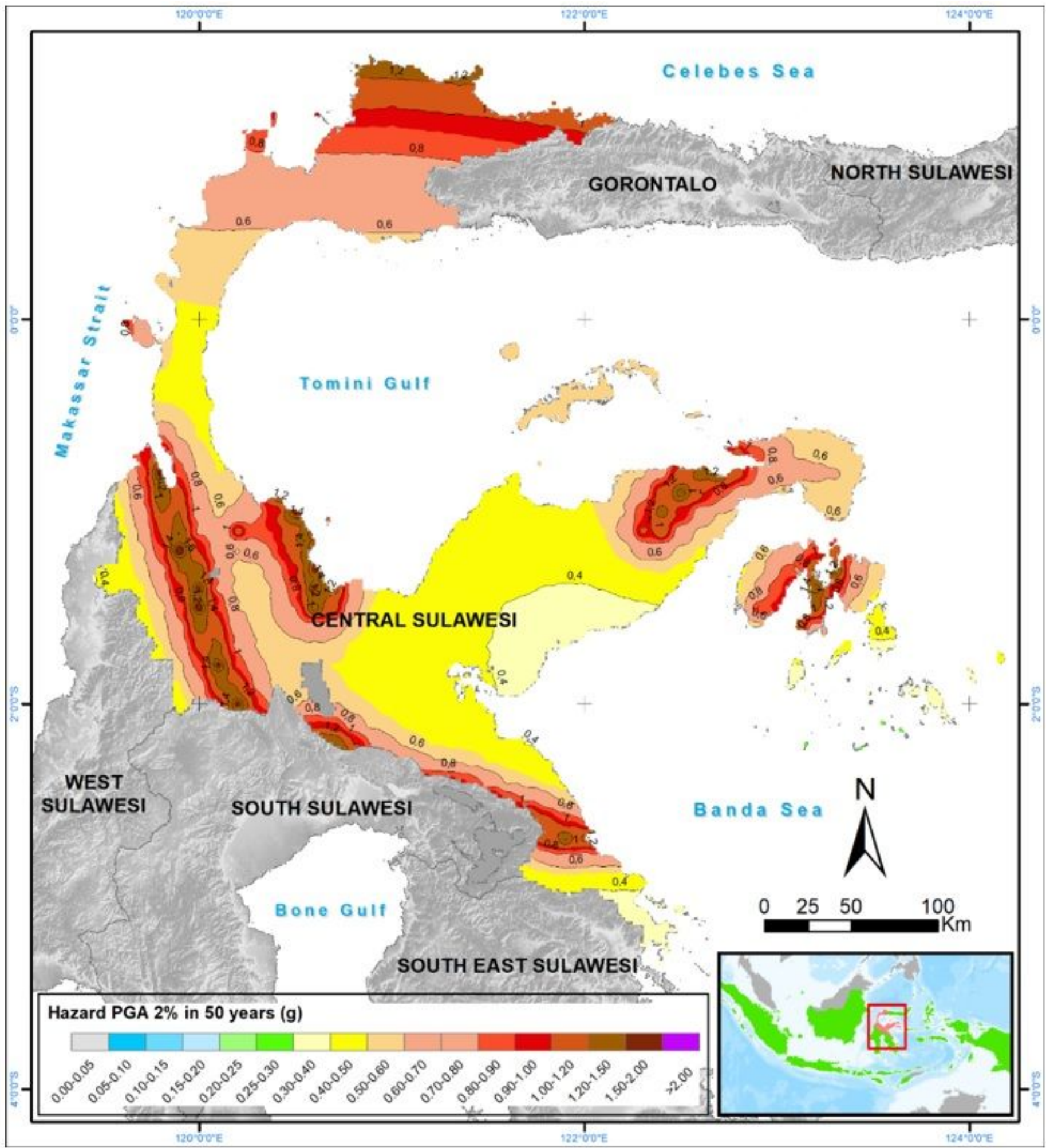

Figure 6

PGA weighting 2475 years with all earthquake sources (4:6 for OpenQuake:USGS PSHA modification) Note: The designations employed and the presentation of the material on this map do not imply the expression of any opinion whatsoever on the part of Research Square concerning the legal status of any country, territory, city or area or of its authorities, or concerning the delimitation of its frontiers or boundaries. This map has been provided by the authors. 

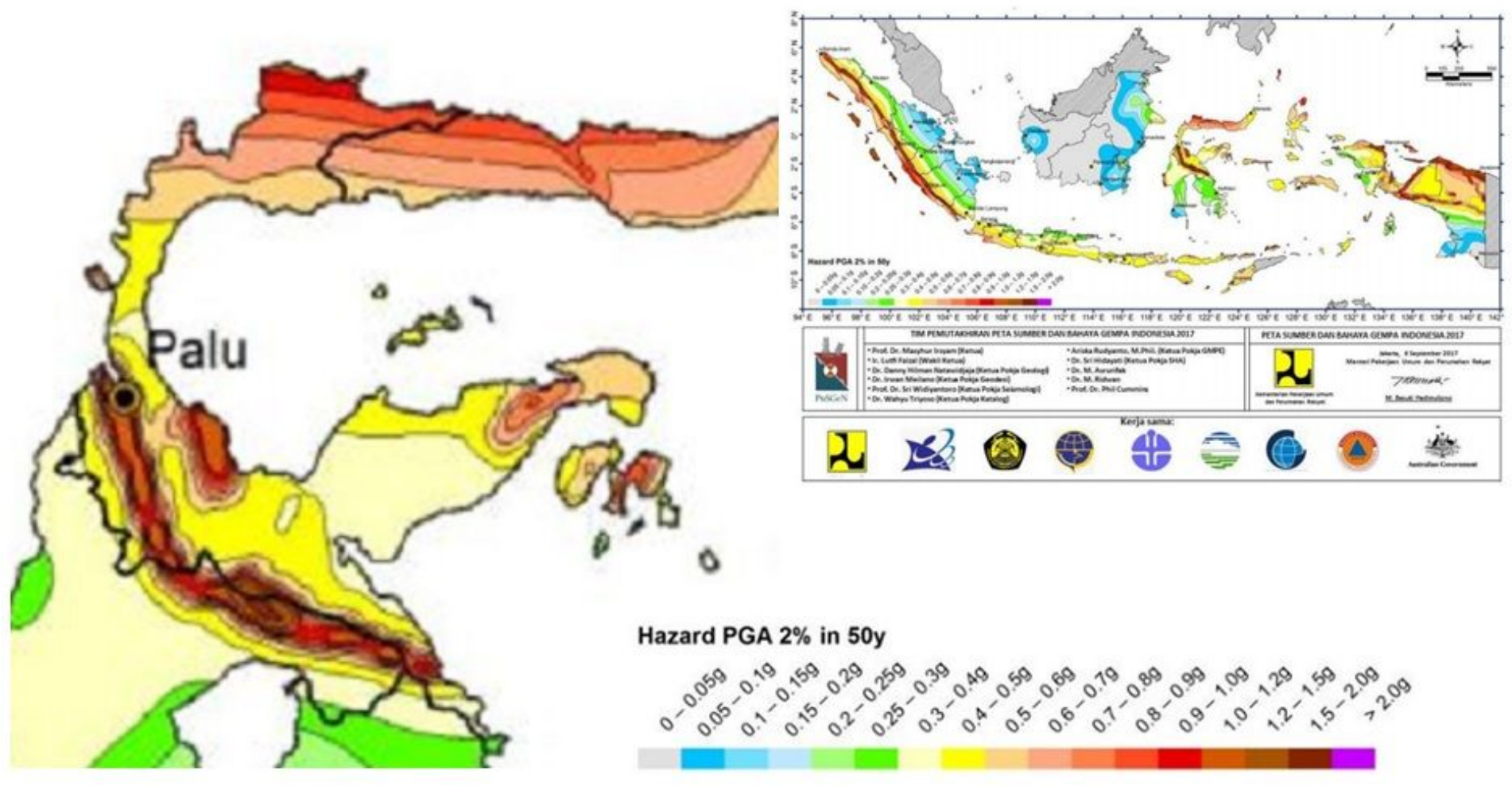

\section{Figure 7}

Map of the 2017 Indonesian Earthquake with 2475 years return period (PusGen 2017). Note: The designations employed and the presentation of the material on this map do not imply the expression of any opinion whatsoever on the part of Research Square concerning the legal status of any country, territory, city or area or of its authorities, or concerning the delimitation of its frontiers or boundaries. This map has been provided by the authors. 